\title{
Physical Activities among Diabetic Patients Attending Diabetic Centers in Kurdistan
}

\author{
Region, Iraq
}

Jawdat Mamand Alhagbaker; Department of Nursing, College of Nursing, Hawler Medical University, Erbil, Iraq.

Sideeq Sadir Ali; Department of Nursing, College of Nursing, Hawler Medical University, Erbil, Iraq.

Correspondence: (sideeq.ali@hmu.edu.krd)

Bekhal Saber Ahmed; Department of Nursing, College of Nursing, Hawler Medical University, Erbil, Iraq.

\begin{abstract}
Background and objective: Physical activity is defined as basic public health for the human body and one of the main treatments for many chronic diseases, especially diabetes mellitus. The aim of this study to assess the level of physical activity among diabetic patients in Kurdistan and determine the association between levels of physical activity and certain variables of socio-demographic and clinical data.

Methods: This cross-sectional study was conducted on 444 diabetes patients in the Kurdistan region of Iraq. The data was collected from 20th June to 10th September 2018 through interviews by using a questionnaire checklist. The data was analyzed by using the statistical package for the social sciences program.

Results: Nearly half of the participants (49.1\%) were middle-aged (36 - 55 years). Majority of them were females (65.1\%), married $(88.1 \%)$ and illiterate $(42.3 \%)$. Nearly half of them (43.9\%) were obese, having high blood glucose levels $(76.8 \%)$ and half of them $(50 \%)$ had hypertension. Majority (75.5\%) of participants were within high levels of physical activity. A highly significant relationship was found between the level of physical activity and sex ( $P$ -value $<0.001)$, presence other chronic diseases, hypertension and heart disease. There were significant relationships between the body mass index and diagnostic duration of diabetes mellitus with the presence of other chronic diseases, presence hypertension, and heart disease.

Conclusion: The majority of diabetic patients had high levels of physical activity, high blood sugar levels, obese, and had many chronic diseases. There was a statistically significant association between the level of physical activity with some variables of sociodemographic and clinical data. There was a highly significant association between body mass index and diagnostic duration of diabetes mellitus with the presence of other chronic disease.
\end{abstract}

Keywords: Physical Activity; Diabetic Mellitus; Kurdistan Region.

Received: 18/9/2019

Accepted: 22/12/2019

Published: 30/5/2020

\section{INTRODUCTION}

Diabetes mellitus is a metabolic disease involving the under production in insulin secretion or action, due to hyperglycemia. When uncontrolled, diabetes mellitus can cause many complications like blindness, renal failure, heart disease, atherosclerosis, and strokes [1]. In addition, exercise and physical activity are the main ways to control blood glucose levels. Exercise can also improve blood circulation, lowers cholesterol and triglyceride levels due to improved muscle tone [2].Nowadays, regular physical activity and exercise enhances body health in a general way and improves quality of life [3]. In type 2 diabetes mellitus, randomized controlled trials illustrated 
that physical activity can delay advancement of impaired glucose tolerance if combined with dietary changes [4]. In spite of this evidence, diabetes organizations very strongly advocate incorporating some level of physical activity in the treatment of diabetes mellitus [5]. The American Diabetes Association (ADA) Council on Exercise recommended that patients with type 2 diabetes should perform resistance exercise at least two times per week on the nonconsecutive days, but three times a week would be preferred. More ideally, physical activity for patients with type 2 diabetes should incorporate regular aerobic activities [6]. Much of the guidelines about physical activity also applied in patients with type 1 diabetes mellitus. People with type 2 diabetes mellitus should be doing at least 150 min per week of moderate to strong physical activity outside their home at least three days per a week, with no more than two days of consecutive activity [7].Despite groups of diabetes patients (both type 1 and type 2) being afraid that their hyperglycemia would act as a barrier to performing such physical activity, it is still advised that they are physically active as an important component of their diabetes management [8]. Globally, prevalence of diabetes mellitus estimated by World Health Organization (WHO) in 1997 was more than 135 million and expected to increase by the year 2025 by $120 \%$ [9]. According to the WHO, prevalence of diabetes mellitus among patients 18 years of age and over was raised; in 1980 it was $4.7 \%$ but in 2014 it was $8.5 \%$. According to their estimates, in 2016, diabetes mellitus was considered as the seventh leading cause of death, and estimated 1.6 million persons' deaths were caused by diabetes mellitus directly [10]. Shaw et al found that the world prevalence of diabetes mellitus among adults (aged 20 -79 years) was 285 million adults (6.4\%) in 2010, and will be increased to 439 million
(7.7\%) by 2030 [11].Prevalence of diabetes increased in all the countries and researchers noted the role of physical activity among diabetic patients in controlling glucose levels and decreasing complications. The researchers intended to assess the levels of physical activity and determine the association between levels of physical activity with socio demographical and clinical data. They also seek to determine the, if any, association between the presence of other diseases with the BMI and diagnostic duration of diabetes mellitus.

\section{METHODS}

A cross-sectional study was carried out in the three Diabetes Centers that are available in the Iraqi Kurdistan Region, namely Layla Qasm Diabetes Center in Erbil City, Diabetes \& Endocrine Center in Sulaimania City and Duhok Diabetes Center in Duhok City. Among 88,442 of diabetic patients who were registered in the registrations department of these diabetic centers, 62,767 of them were adults (Erbil 36,325, Sulaimania 3,098 and Duhok 23,344), 444 nonprobability (purposive) adult diabetes patients participated in this study (Erbil 176, Sulaimania 140 and Duhok 128). These diabetic patients were visiting the diabetic centers monthly for their medical checkups. The proportionate of sample size became approximately 400 participants for all three Centers; Erbil, Sulaimani and Duhok were 158, 136 and 106 participants respectively. The sample size was increased to account for a potentially higher prevalence of diabetes related to undiagnosed cases in the population. The sample size was estimated and calculated by using the formula for calculating the minimum sample size for cross-sectional studies. A sample size of 113 participants was estimated based on having a prevalence of diabetes of 0.08 with a degree of precision of $5 \%$ [12]. The inclusion criteria included 
all diabetic patients who attend the diabetic center in those Centers that mentioned above. Patients who refused to participate and with limited communication wereexcluded. The investigators used the International Physical Activity Questionnaire (IPAQ), short form in the survey and data was collected through using the interview technique. Part 1: The sociodemographic part, which included data about age, sex, marital status, location of the home, occupational status, and educational level. Part 2: The clinical information part, which included the body mass index (BMI), diagnostic duration of diabetes mellitus, presence of other chronic diseases and type of chronic disease. Part 3: The questions of IPAQ short form were about specific types of physical activities during the seven days, under the following four domains: leisure time; domestic and gardening; work-related; and transportrelated physical activities. Three levels of physical activity were assessed which included; walking; moderate-intensity activities (e.g., gardening, washing the car or clothes by hand, or bicycling at normal speed); and vigorous-intensity activities (e.g., heavy weightlifting, running or swimming). Total physical activity of Metabolic Equivalent Task (MET)-minutes/week = Walking + Moderate + Vigorous MET minutes/week scores. Note: MET scores of 3.3, 4.0 and 8.0 for walking, moderate and vigorous intensity activity, did not reported days per week in which any of walking, moderate and vigorous intensity activity was reported. In regards to these three categories of physical activity, they were defined by IPAQ as Category 1 being low physical activity level, Category 2 being moderate physical activity level including at least 20 minutes of vigorous intensity level activities done per day for 3 or more days per week, or at least 30 minutes of moderate intensity activity per day for five or more days weekly, or 5 or more days of any combination of walking, moderateintensity or vigorous intensity level activities reaching a minimal total physical activity of at least 600 MET minutes/week, and Category 3; high physical activity level conceived as vigorous-intensity activity, at least 3 days reaching a minimal total physical activity of at least 1500 MET-minutes/ week, or 5 or more days of any combination of walking, moderate-intensity or vigorous intensity activities reaching a minimal total physical activity of at least 3000 MET-minutes/week. All of the activities were set apart as IPAQ scoring protocol $[13,14]$. The study was carried out from May 1st, 2018 to August 1st, 2019. The data was collected from June 20th to September 10th, 2018. Official permission was obtained from the directorates of health from Erbil, Suleimania and Duhok. During the survey, the researchers briefly explained the purpose of the survey, obtained verbal consent from each participant, and completed the questionnaire by direct interview. Data was analyzed by the Statistical Package for the Social Sciences (SPSS, version 20). Descriptive and inferential statistics were used in this study with descriptive statistics used for calculating frequencies and percentages of participants. The association between levels of physical activity with the different sociodemographic and clinical characteristics of the participants was assessed by using inferential statistics and Chi-Square test. A P value of $\leq 0.05$ was considered statistically significant.

\section{RESULTS}

Table 1 shows the socio-demographic characteristics of diabetic patients. $39.6 \%$ of the study participants were in Erbil city. Nearly half of the participants (49.1\%) were middle-aged (36 - 55 years old). Majority of the study participants were 
female (65.1\%). Most of them were married $(88.1 \%)$ and from urban areas $(83.8 \%)$. Finally, $60.6 \%$ of them were unemployed and $42.3 \%$ of them were illiterate. Table 2 demonstrates the clinical information of the diabetic patients. Around $44 \%$ of the diabetic patients were obese and $54.5 \%$ were diagnosed between 1 and 9 years duration. Regarding the blood glucose level, majority of the participants (76.8\%) had a high blood glucose level. Regarding presence of other diseases, half of them (50\%) had hypertension. Table 3 explores the levels of physical activity of diabetic patients with the majority (75.5\%) of them being at a high level of physical activity, $15.3 \%$ of them were at moderate level of physical activity and $9.2 \%$ were at low level of physical activity. Table 4 focuses on the association between sociodemographic data and levels of physical activity of diabetic patients. There was a very high significant association between the sex of patients and the level of physical activity ( $P$-value $<0.001)$ and another significant association was found between age groups and levels of physical activity with ( $P$-value $=0.032$ ). Table 5 displays the association between some of the clinical information variables with the levels of physical activity. A highly significant relationship was found between levels of physical activities with the presence of other chronic diseases, such as hypertension and heart disease ( $P$-value $<0.001$ ). Another significant relationship was found with the presence of retinopathy ( $P$-value $=0.009$ ). Table 6 shows the association between BMI groups with the presence of some chronic disease and complication of diabetes mellitus. There was a highly significant relationship between $\mathrm{BMI}$ with the presence other chronic diseases ( $P$-value $=0.002$ ) and presence of hypertension ( $P$ value $=0.001$ ). Table 7 shows the relationships between duration of diagnoses of diabetes mellitus with some chronic disease and complication of diabetes mellitus. There was a highly significant relationship found between groups diagnostic duration with the presence of heart disease ( $P$-value $<0.001$ ), and high significant relationship found between presence other chronic diseases $(P$-value $=0.001)$, presence hypertension ( $P$-value $=0.007)$, presence kidney disease $(P$-value $=0.003)$, finally, a significant association was also found with the presence of anemia $(P$-value $=0.024)$.

Table 1: Socio-demographic characteristics of diabetic patients

\begin{tabular}{|c|c|c|c|}
\hline \multirow{2}{*}{\multicolumn{2}{|c|}{ Socio-demographic Variables }} & \multicolumn{2}{|c|}{$N=444$} \\
\hline & & \multirow{2}{*}{$\frac{\mathbf{F}}{176}$} & \multirow{2}{*}{$\frac{(\%)}{(39.7)}$} \\
\hline Residential & Erbil & & \\
\hline area & Sulaimania & 140 & $(31.5)$ \\
\hline & Dahuk & 128 & $(28.8)$ \\
\hline \multirow[t]{3}{*}{ Age Groups } & $\begin{array}{l}18-35 \text { Years Old } \\
\text { ( Young Adult ) }\end{array}$ & 20 & $(4.5)$ \\
\hline & $\begin{array}{l}36-55 \text { Years Old } \\
\text { (Middle-Aged } \\
\text { Adults) }\end{array}$ & 218 & (49.1) \\
\hline & $\begin{array}{l}56 \text { Years Old and } \\
\text { above (Older Adult) }\end{array}$ & 206 & $(46.4)$ \\
\hline \multirow{2}{*}{$\begin{array}{l}\text { Sex of Par- } \\
\text { ticipants }\end{array}$} & Male & 155 & (34.9) \\
\hline & Female & 289 & $(65.1)$ \\
\hline \multirow{2}{*}{$\begin{array}{l}\text { Marital } \\
\text { Status }\end{array}$} & Married & 391 & $(88.1)$ \\
\hline & Widowed & 35 & (7.9) \\
\hline \multirow{3}{*}{$\begin{array}{l}\text { Location of } \\
\text { Home }\end{array}$} & Urban & 372 & $(83.8)$ \\
\hline & Sub-Urban & 53 & (11.9) \\
\hline & Rural & 19 & $(4.3)$ \\
\hline \multirow{4}{*}{$\begin{array}{l}\text { Occupation- } \\
\text { al Status of } \\
\text { Participants }\end{array}$} & Self Employed & 44 & (9.9) \\
\hline & Retired & 60 & $(13.5)$ \\
\hline & $\begin{array}{l}\text { Governmental Em- } \\
\text { ployee }\end{array}$ & 71 & (16) \\
\hline & Unemployed & 269 & $(60.6)$ \\
\hline \multirow{6}{*}{$\begin{array}{l}\text { Educational } \\
\text { Status } \\
\text { of partici- } \\
\text { pants }\end{array}$} & Illiterate & 188 & $(42.3)$ \\
\hline & Can read and write & 85 & (19.1) \\
\hline & Primary School & 90 & (20.3) \\
\hline & Secondary School & 36 & (8.1) \\
\hline & Institute or College & 45 & (10.1) \\
\hline & Total & 444 & $(100)$ \\
\hline
\end{tabular}


Table 2: Medical information of diabetic patients

\begin{tabular}{|c|c|c|c|}
\hline \multirow{2}{*}{ Clinical Information Variables } & & \multicolumn{2}{|r|}{$N=444$} \\
\hline & & $\mathbf{F}$ & (\%) \\
\hline \multirow[t]{4}{*}{ BMI Groups of Participants } & Under Weight & 3 & $(0.7)$ \\
\hline & Normal Weight & 81 & $(18.2)$ \\
\hline & Over Weight & 165 & $(37.2)$ \\
\hline & Obese & 195 & (43.9) \\
\hline \multirow{4}{*}{$\begin{array}{l}\text { Diagnostic duration of Diabetes } \\
\text { Mellitus }\end{array}$} & 1 - 9 Years & 242 & $(54.5)$ \\
\hline & $10-19$ Years & 154 & $(34.7)$ \\
\hline & $20-29$ Years & 34 & (7.7) \\
\hline & $30-40$ Years & 14 & $(3.2)$ \\
\hline \multirow[t]{3}{*}{ Level of Blood Glucose } & Normal level of blood glucose & 28 & (6.3) \\
\hline & Above normal level of blood glucose & 75 & $(16.9)$ \\
\hline & High level of blood glucose & 341 & $(76.8)$ \\
\hline \multirow[t]{3}{*}{ Presence of other chronic diseases } & Yes & 279 & $(62.8)$ \\
\hline & No & 165 & $(37.2)$ \\
\hline & Total & 444 & $(100)$ \\
\hline \multirow{8}{*}{$\begin{array}{l}\text { Type of chronic disease } \\
\left({ }^{*} N=279\right)\end{array}$} & Hypertension & 222 & (50) \\
\hline & Heart disease & 109 & $(24.5)$ \\
\hline & Kidney Disease & 45 & (10.1) \\
\hline & Retinopathy & 60 & $(13.5)$ \\
\hline & Anemia & 30 & $(6.8)$ \\
\hline & Stroke & 3 & $(0.7)$ \\
\hline & Asthma & 8 & (1.8) \\
\hline & Neuropathy & 48 & (10.8) \\
\hline
\end{tabular}

Table 3: Levels of Physical Activity

\begin{tabular}{lll}
\hline Physical Activity & & $\mathbf{N}=\mathbf{4 4 4}$ \\
\hline Low Level of Physical Activity & 41 & $(9.2)$ \\
Moderate Level of Physical Activity & 68 & $(15.3)$ \\
High Level of Physical Activity & 335 & $(75.5)$ \\
Total & & \\
\end{tabular}


Table 4: Association between socio-demographic variables and levels of physical activity

\begin{tabular}{|c|c|c|c|c|c|}
\hline \multirow[b]{2}{*}{$\begin{array}{l}\text { Clinical Information } \\
\text { Variables }\end{array}$} & \multirow[b]{2}{*}{ Sub-groups } & \multicolumn{3}{|c|}{ Levels of physical activity } & \multirow[b]{2}{*}{ P-value } \\
\hline & & $\begin{array}{c}\text { Low Lev- } \\
\text { el of } \\
\text { Physical } \\
\text { Activity } \\
\text { (\%) }\end{array}$ & $\begin{array}{c}\text { Moderate } \\
\text { Level of } \\
\text { Physical } \\
\text { Activity } \\
\text { (\%) }\end{array}$ & $\begin{array}{c}\text { High } \\
\text { Level of } \\
\text { Physical } \\
\text { Activity } \\
\text { (\%) }\end{array}$ & \\
\hline \multirow[t]{3}{*}{ Age Groups } & $\begin{array}{l}18 \text { - } 35 \text { Years Old ( Young } \\
\text { Adult ) }\end{array}$ & $(0.5)$ & $(0.5)$ & $(3.6)$ & 0.032 \\
\hline & $\begin{array}{l}36 \text { - } 55 \text { Years Old (Middle- } \\
\text { Aged Adults) }\end{array}$ & $(2.5)$ & $(7.2)$ & (39.4) & \\
\hline & $\begin{array}{l}56 \text { Years Old and above } \\
\text { (Older Adult) }\end{array}$ & $(6.3)$ & $(7.7)$ & (32.4) & \\
\hline \multirow[t]{3}{*}{ Sex of Participants } & Male & $(4.1)$ & $(8.3)$ & $(22.5)$ & $<0.001$ \\
\hline & Female & $(5.2)$ & $(7.0)$ & (52.9) & \\
\hline & Widowed & $(1.4)$ & $(1.4)$ & $(5.2)$ & \\
\hline \multirow[t]{4}{*}{$\begin{array}{l}\text { Occupational Status } \\
\text { of Participants }\end{array}$} & Self Employed & $(0.2)$ & $(2.3)$ & $(7.4)$ & 0.395 \\
\hline & Retired & $(1.4)$ & $(2.7)$ & (9.5) & \\
\hline & Governmental Employee & $(1.6)$ & $(2.5)$ & (11.9) & \\
\hline & Unemployed & $(6.1)$ & (7.9) & $(46.6)$ & \\
\hline \multirow{6}{*}{$\begin{array}{l}\text { Educational Status of } \\
\text { participants }\end{array}$} & Illiterate & $(4.5)$ & $(4.5)$ & (33.3) & 0.484 \\
\hline & Can read and write & $(1.1)$ & $(3.4)$ & $(14.6)$ & \\
\hline & Primary & $(1.8)$ & $(3.6)$ & (14.9) & \\
\hline & Secondary & $(0.9)$ & $(1.6)$ & $(5.6)$ & \\
\hline & Institute or College & $(0.9)$ & $(2.3)$ & $(7.0)$ & \\
\hline & Total & $(9.2)$ & (15.3) & (75.5) & \\
\hline
\end{tabular}


Table 5: Association between clinical information and levels of physical activity

\begin{tabular}{|c|c|c|c|c|c|}
\hline \multirow[b]{2}{*}{ Clinical Information Variables } & \multirow[b]{2}{*}{ Sub-groups } & \multicolumn{4}{|c|}{ Levels of physical activity } \\
\hline & & $\begin{array}{l}\text { Low Level of } \\
\text { Physical Ac- } \\
\text { tivity } \\
\text { (\%) }\end{array}$ & $\begin{array}{l}\text { Moderate } \\
\text { Level of Physi- } \\
\text { cal Activity } \\
\text { (\%) }\end{array}$ & $\begin{array}{c}\text { High Level } \\
\text { of Physical } \\
\text { Activity } \\
\text { (\%) }\end{array}$ & $\begin{array}{c}\text { P- } \\
\text { value }\end{array}$ \\
\hline \multirow[t]{4}{*}{ BMI Groups of Participants } & Under Weight & (0) & (0) & $(0.7)$ & 0.753 \\
\hline & Normal Weight & (1.4) & (2.3) & (14.6) & \\
\hline & Over Weight & (3.6) & $(5.2)$ & (28.4) & \\
\hline & Obese & (4.3) & (7.9) & (31.8) & \\
\hline \multirow{4}{*}{$\begin{array}{l}\text { Diagnostic Duration of Partici- } \\
\text { pants }\end{array}$} & 1 - 9 Years & (3.8) & (8.6) & (42.1) & 0.610 \\
\hline & $10-19$ Years & (4.3) & $(4.7)$ & (25.7) & \\
\hline & $20-29$ Years & $(0.7)$ & $(1.6)$ & (5.4) & \\
\hline & $30-40$ Years & $(0.5)$ & $(0.5)$ & (2.3) & \\
\hline \multirow{2}{*}{$\begin{array}{l}\text { Did you have Any Other } \\
\text { Chronic Diseases }\end{array}$} & Yes & (7.9) & (11.3) & (43.7) & $<0.001$ \\
\hline & No & (1.4) & $(4.1)$ & (31.8) & \\
\hline \multirow[t]{2}{*}{ Did you have Hypertension } & No & $(2.3)$ & (6.1) & (41.7) & $<0.001$ \\
\hline & Yes & (7.0) & $(9.2)$ & (33.8) & \\
\hline \multirow[t]{2}{*}{ Did you have Heart disease } & No & (5.4) & (9.7) & $(60.4)$ & $<0.001$ \\
\hline & Yes & (3.8) & $(5.6)$ & (15.1) & \\
\hline \multirow[t]{2}{*}{ Did you have Kidney Disease } & No & (8.1) & (14.4) & (67.3) & 0.432 \\
\hline & Yes & $(1.1)$ & $(0.9)$ & (8.1) & \\
\hline \multirow[t]{2}{*}{ Did you have Retinopathy } & No & (7.9) & $(11.5)$ & (67.1) & 0.009 \\
\hline & Yes & (1.4) & (3.8) & (8.3) & \\
\hline \multirow[t]{2}{*}{ Did you have Anemia } & No & (8.3) & $(14.2)$ & (70.7) & 0.687 \\
\hline & Yes & (0.9) & (1.1) & (4.7) & \\
\hline \multirow[t]{2}{*}{ Did you have Stroke } & No & (9.2) & (15.1) & (75.0) & 0.622 \\
\hline & Yes & (0) & $(0.2)$ & $(0.5)$ & \\
\hline \multirow[t]{2}{*}{ Did you have Neuropathy } & No & (8.1) & $(13.3)$ & (67.8) & 0.723 \\
\hline & Yes & (1.1) & (2.0) & (7.7) & \\
\hline \multirow[t]{4}{*}{$\begin{array}{l}\text { Normality and abnormality of } \\
\text { Blood Sugar }\end{array}$} & $\begin{array}{l}\text { Normal level of } \\
\text { blood sugar }\end{array}$ & (0.7) & (0.7) & (3.4) & 0.570 \\
\hline & $\begin{array}{l}\text { Above normal } \\
\text { level of blood } \\
\text { sugar }\end{array}$ & $(0.3)$ & (1.0) & (12.9) & \\
\hline & $\begin{array}{l}\text { High level of } \\
\text { blood sugar }\end{array}$ & (6.8) & (15.0) & $(59.2)$ & \\
\hline & Total & (7.8) & (16.7) & (75.5) & \\
\hline
\end{tabular}


Table 6: Association between clinical information and BMI groups

\begin{tabular}{lcccccc}
\hline & & \multicolumn{3}{c}{ BMI Groups of Participants } \\
& & Under & Normal & Over & & \\
Some variable & & Weight & Weight & Weight & Obese & P-value \\
\hline \multirow{2}{*}{ Did you have Any Other Chronic } & Yes & $(0)$ & $(\%)$ & $(\%)$ & $(\%)$ & \\
Diseases & No & $(100)$ & $(49.4)$ & $(63.0)$ & $(69.2)$ & $\mathbf{0 . 0 0 2}$ \\
Did you have Hypertension & No & $(100)$ & $(64.2)$ & $(37.0)$ & $(30.8)$ & \\
& Yes & $(0)$ & $(35.8)$ & $(47.3)$ & $(59.0)$ & \\
Did you have Heart disease & No & $(100)$ & $(82.7)$ & $(77.6)$ & $(70.3)$ & $\mathbf{0 . 0 8 9}$ \\
& Yes & $(0)$ & $(17.3)$ & $(22.4)$ & $(29.7)$ & \\
Did you have Kidney Disease & No & $(100)$ & $(90.1)$ & $(88.5)$ & $(90.8)$ & $\mathbf{0 . 8 3 4}$ \\
& Yes & $(0)$ & $(9.9)$ & $(11.5)$ & $(9.2)$ & \\
Did you have Retinopathy & No & $(100)$ & $(88.9)$ & $(87.3)$ & $(84.6)$ & $\mathbf{0 . 6 7 3}$ \\
& Yes & $(0)$ & $(11.1)$ & $(12.7)$ & $(15.4)$ & \\
Did you have Anemia & No & $(100)$ & $(98.8)$ & $(92.1)$ & $(91.8)$ & $\mathbf{0 . 1 6 3}$ \\
& Yes & $(0)$ & $(1.2)$ & $(7.9)$ & $(8.2)$ & \multirow{2}{*}{ (0) } \\
Did you have Stroke & No & $(100)$ & $(100)$ & $(98.8)$ & $(99.5)$ & $\mathbf{0 . 7 1 6}$ \\
& Yes & $(0)$ & $(0)$ & $(1.2)$ & $(0.5)$ & \\
Did you have Neuropathy & No & $(100)$ & $(88.9)$ & $(88.5)$ & $(89.7)$ & $\mathbf{0 . 0 8 1}$ \\
& Yes & $(0)$ & $(11.1)$ & $(11.5)$ & $(10.3)$ & \\
\hline
\end{tabular}

Table 7: Association between clinical information and group's diagnostic duration

\begin{tabular}{lcccccc}
\hline & & & \multicolumn{3}{c}{ Diagnostic Duration of Participants } & \\
\cline { 6 - 7 } & & $\mathbf{1}-\mathbf{9}$ & $\mathbf{1 0 - 1 9}$ & $\mathbf{2 0 - 2 9}$ & $\mathbf{3 0 - 4 0}$ & \\
Some variable & & Years & Years & Years & Years & P-value \\
Did you have Any Other Chronic & Yes & $(54.5)$ & $(71.4)$ & $(76.5)$ & $(78.6)$ & $\mathbf{0 . 0 0 1}$ \\
Diseases & No & $(45.5)$ & $(28.6)$ & $(23.5)$ & $(21.4)$ & \\
Did you have Hypertension & No & $(57.0)$ & $(44.2)$ & $(32.4)$ & $(35.7)$ & $\mathbf{0 . 0 0 7}$ \\
& Yes & $(43.0)$ & $(55.8)$ & $(67.6)$ & $(64.3)$ & \\
Did you have Heart disease & No & $(83.9)$ & $(68.2)$ & $(55.9)$ & $(57.1)$ & $<0.001$ \\
& Yes & $(16.1)$ & $(31.8)$ & $(44.1)$ & $(42.9)$ & \\
Did you have Kidney Disease & No & $(92.6)$ & $(90.3)$ & $(76.5)$ & $(71.4)$ & $\mathbf{0 . 0 0 3}$ \\
& Yes & $(7.4)$ & $(9.7)$ & $(23.5)$ & $(28.6)$ & \\
Did you have Retinopathy & No & $(88.8)$ & $(85.7)$ & $(76.5)$ & $(78.6)$ & $\mathbf{0 . 1 7 9}$ \\
& Yes & $(11.2)$ & $(14.3)$ & $(23.5)$ & $(21.4)$ & \\
Did you have Anemia & No & $(95.9)$ & $(91.6)$ & $(88.2)$ & $(78.6)$ & $\mathbf{0 . 0 2 4}$ \\
Did you have Stroke & Yes & $(4.1)$ & $(8.4)$ & $(11.8)$ & $(21.4)$ & \\
& No & $(99.2)$ & $(99.4)$ & $(100)$ & $(100)$ & $\mathbf{0 . 9 3 8}$ \\
Did you have Neoropathy & Yes & $(0.8)$ & $(0.6)$ & $(0)$ & $(0)$ & \\
& No & $(92.6)$ & $(85.1)$ & $(85.3)$ & $(85.7)$ & $\mathbf{0 . 0 9 9}$ \\
& Yes & $(7.4)$ & $(14.9)$ & $(14.7)$ & $(14.3)$ & \\
\hline & & & & & & \\
\hline
\end{tabular}




\section{DISCUSSION}

Physical inactivity could be a global health problem as most studies focused and discussed leisure time physical activity, while physical activity at work, domestic and amid transport has not been assessed [15]. Physical activity in adults with type 2 diabetes significantly increases by interventions of their behavioral [16]. Such activity is linked to improving personal fitness and therefore could reduce the complications of chronic diseases and disabilities preventing an unhealthy weight [3].

The study was assessed by using IPAQ, a suitable instrument and simple measurement to assess overall physical activity for diabetic patients. IPAQ also provides information for the best way for control of blood glucose without using prescription drugs. The study determined that most of the study sample had a high level of physical activity. However, the majority of them had other chronic illnesses which further complicated their diabetes symptoms. Moreover, nearly half of them were obese. The reason may be that the majority of them neglected to manage and control their blood glucose because as their blood glucose was high and may have neglected taking their medications. This study did not agree with that of Acheampong in 2011 which was conducted on 350 diabetic patients in Kumasi, Ghana with more than half of their study sample having not received formal education at all, and a greater number of these patients not performing any physical exercise [17].

A very high significant relationship was shown between the sex of patients and the level of physical activity as well as between the age groups and the levels of physical activity. This may be due to nearly half the study population being middle aged and the highest level of physical activity is typically found within this age group. The result agreed with the cross- sectional study conducted on 320 patients with type two diabetes in Hamadan, Iran; there was a significant $(P<0.05)$ relationship between physical activity level and age group [18], The study was also agreed with a crosssectional nation-wide study conducted by Sibai et al., 2013 on 2,195 haphazardly chosen adults aged 25 years and older in Lebanese governorates. They found in their study that physical activity was significantly higher among the middle-age group [19].A very high significant association was found between levels of physical activity and the presence of other chronic diseases, especially with the presence of hypertension and heart disease, as well as with the presence of retinopathy. A high significant association was found between BMI with the presence of other chronic disease, especially with the presence of hypertension. The reason behind this could be that diabetes could lead to various complications in the arteries and arterioles making them more susceptible to developing atherosclerosis. Also, the participants in this study majority of them were obese and high level of blood glucose. The result is similar to the findings of the previous cross-sectional study conducted by Ali et al in determining the prevalence of diabetes mellitus complications among patients in Duhok, Erbil and Suleimania cities of Iraq. Their study showed a significant association between some diabetes mellitus complications with demographic variables and showed highly significant differences in diabetic laboratory tests with BMI [9]. In addition, the results of our study were supported by the cross-sectional study conducted in 2009-2010 in Spain by Brugnara et al. In this study, low physical activity especially among women is associated with several cardiovascular risk factors and could 
be responsible with an increasing prevalence of obesity and diabetes [20]. There was a highly significant association found between group's diagnostic duration with presence of other disease, especially with the presence of heart disease and a high significant association with presence of other chronic diseases, like hypertension, kidney disease, anemia and normality and abnormality of blood sugar. For similar reasons, nearly half of the study group had been diagnosed for diabetes Mellitus between one to nine years ago, but the majority of them had other chronic diseases that indicated diabetes mellitus complications. Nearly half of them were obese and most of them had high blood glucose levels. Petrie et al., 2018 reported that diabetes and hypertension are closely related together and diabetes is related to an increased risk of cardiovascular disease, which is overstated with coexistent hypertension [21]. The study was in agreement with the non-experimental, cross-sectional study of Gutierrez et al., (2018) conducted in Tabuk city in Saudi Arabia. In this study, researchers studied 432 participants and the results in their study showed a positive correlation between $\mathrm{BMI}$ with hypertension and diabetes mellitus $(P<0.001)$; whereas the relationship between hypertension and diabetes mellitus was ( $P$ $<0.001)$. Thus, this relationship was the strongest correlation observed among those variables [22].In general, the study revealed that the majority of the study group was at a high level of physical activity, while the majority of diabetes patients were overweight and obese, had other chronic diseases, high levels of blood glucose, and were illiterate. Not having statistically relationships between the levels of physical activity with the majority of the variables may be due to the limitations of the study such as lack of information about factors that controlling blood sugar such as; family history, illness, side effects of steroids or anti-psychotic medication, overconsumption of foods, stress, menstrual periods, pain and dehydration. Also, our study only included asking about and not observing the exercise. Patients might not have answered the question correctly or honestly.

\section{CONCLUSION}

The study concluded that the physical activity among diabetic patients was high, but because of negligence of other parts of treating diabetes mellitus disease by the patients such as diet and medication, blood sugar remained high, patients remained obese and other side effects were present as well. There was a very high significant association between the levels of physical activity and BMI and some side effects, as well as an association between of level of physical activity with the patients' sex and age.

\section{CONFLICTS OF INTEREST}

The authors report no conflicts of interest and any sources of financial support.

\section{REFERENCES}

[1] Williams LS, Hopper PD. Understanding Medical-Surgical Nursing. 2nd ed. USA, Philadelphia: F.A. Davis Company Publishing; 2003. p. 645-7.

[2] Timby BK, Smith NE. Introductory medicalsurgical nursing. USA, Philadelphia: 10th ed. Wiley-Blackwell Publishing; 2010. p. 788.

[3] Haskell WL, Lee I-M, Pate RR, Powell KE, Blair SN, Franklin BA, et al. Physical activity and public health: updated recommendation for adults from the American College of Sports Medicine and the American Heart Association. Medicine and Science in Sports and Exercise. 39(8), 1423-1434. Available from:DOI:10.1161CIRCULATION.107.18564 9 [Accessed: 18th March 2019]. 
[4] Knowler WC, Barrett-Connor E, Fowler SE, Hamman RF, Lachin JM, Walker EA, et al. Reduction in the incidence of type 2 diabetes with lifestyle intervention or metformin. The New England Journal of Medicine. 2002; 346 (6): 393-403. Available from: doi: 10.1056/NEJMoa012512 [Accessed: 18th March 2019].

[5] Rydén L, Standl E, Bartnik M, Van den Berghe G, Betteridge J, De Boer M-J, et al. Guidelines on diabetes, pre-diabetes, and cardiovascular diseases: executive summary: The Task Force on Diabetes and Cardiovascular Diseases of the European Society of Cardiology (ESC) and of the European Association for the Study of Diabetes (EASD). European Heart Journal. 2007; 28 (1):88-136. Available from: DOI: 10.1093/ eurheartj/ehl260 [Accessed: 18th March 2019].

[6] Moy CS, Songer TJ, LaPorte RE, Dorman JS, Kriska AM, Orchard TJ, et al. Insulindependent diabetes mellitus, physical activity, and death. American Journal of Epidemiology. 1993; 137 (1): 74-81. Available from: DOI: $\quad 10.1093 / o x f o r d j o u r n a l s . a j e . a 116604$ [Accessed: 18th March 2019].

[7] Colberg SR, Sigal RJ, Fernhall B, Regensteiner JG, Blissmer BJ, Rubin RR, et al. Exercise and type 2 diabetes: the American College of Sports Medicine and the American Diabetes Association: joint position statement executive summary. Diabetes Care. 2010; 33 (12): 2692-6.Available from: DOI: 10.2337/dc10-9990 [Accessed: 18th March 2019].

[8] Brazeau A-S, Rabasa-Lhoret R, Strychar I, Mircescu H. Barriers to physical activity among patients with type 1 diabetes. Diabetes care. 2008; 31(11): 2108-9. Available from: DOI: 10.2337/dc08-0720 [Accessed: 18th March 2019].

[9] Ali NSM, Allela OQB, Salih HM, Ahmed IH. Prevalence of Type 2 Diabetes Associated Complications ion Kurdistan Region Iraq. Journal of basic and clinical physiology and pharmacology. 2018; 9 (2): 262-269.

[10] Nadeau KJ, Regensteiner JG, Bauer TA, Brown MS, Dorosz JL, Hull A, et al. Insulin resistance in adolescents with type 1 diabetes and its relationship to cardiovascular function. The Journal of clinical endocrinology and metabolism. 2010; 95 (2): 513-21. Available from: DOI: 10.1210/jc.2009-1756 [Accessed: 18th March 2019].
[11] Shaw JE, Sicree RA, Zimmet PZ. Global estimates of the prevalence of diabetes for 2010 and 2030. Diabetes Research and Clinical Practice. 2010; 1; 87 (1): 4-14. Available from: DOI: 10.1016/ j.diabres.2009.10.007 [Accessed: 18th March 2019].

[12] Araoye MO. Research methodology with statistics for health and social sciences. 1st ed. Nathadex: Ilorin Publishing; 2004;p. 120.

[13] Hasandokht T, Farajzadegan Z, Siadat ZD, Paknahad Z, Rajati F. Lifestyle interventions for hypertension treatment among Iranian women in primary health-care settings: Results of a randomized controlled trial. Journal of research in medical sciences.2015;20 (1): 54.

[14] Duarte CK, de Almeida JC, Merker AJ, de Oliveira Brauer F, da Costa Rodrigues T. Physical activity level and exercise in patients with diabetes mellitus. Revista da Associacao Medica Brasileira. 2012; 58 (2):215-21.

[15] Agha SY, Al Dobbagh SA. Level of physical activity among teaching and support staff in the education sector in Dohuk, Iraq. Eastern Mediterranean Health Journal. 2010; 16 (12): 1278-84. Available from: DOI:10.26719/2010.16.12.127[Accessed: 18th March 2019].

[16] Colberg SR, Sigal RJ, Yardley JE, Riddell MC, Dunstan DW, Dempsey PC, et al. Physical activity/exercise and diabetes: a position statement of the American Diabetes Association. Diabetes care.2016; 1 39 (11): 2065-79 .Available from: DOI: 10.2337/dc16-1728 [Accessed: 18th March 2019].

[17] Acheampong AY. The Relation between diabetes with hypertension and other cardiovascular risk factors using logit and probit model. (Doctoral dissertation) 2011. (Accessed July 15, 2018, Available from: http://ir.knust.edu.gh/ bitstream/123456789/4067/1/ ABRAHAM\%2OYEBOAH\% 20ACHEAMPONG\%20THESIS202011.pdf) [Accessed: 18th March 2019].

[18] Fattahi A, Barati M, Bashirian S, Heydari Moghadam R. Physical activity and its related factors among type 2 diabetic patients in Hamadan. Iranian Journal of Diabetes and Obesity. 2014; 6 (2): 85-92. 
[19] Sibai AM, Costanian C, Tohme R, Assaad S, Hwalla N. Physical activity in adults with and without diabetes: from the 'high-risk 'approach to the 'population-based 'approach of prevention. BMC public health. 2013; 13 (1): 1002. Available from: doi: 10.1186/1471-2458-13-1002[Accessed:18th March 2019].

[20] Brugnara L, Murillo S, Novials A, RojoMartínez G, Soriguer F, Goday A, et al. Low physical activity and its association with diabetes and other cardiovascular risk factors: a nationwide, population-based study. PIOS one. 2016; 11 (8): e0160959. Available from: DOI: 10.1371/journal.pone.0160959 [Accessed: 18th March 2019].

[21] Petrie JR, Guzik TJ, Touyz RM. Diabetes, hypertension, and cardiovascular disease: clinical insights and vascular mechanisms. The Canadian Journal of Cardiology. 2018; 34 (5): 575-84. Available from: DOI: 10.1016/ j.cjca.2017.12.005 [Accessed: 18th March 2019].

[22] Gutierrez J, Alloubani A, Mari M, Alzaatreh M. Cardiovascular disease risk factors: Hypertension, diabetes mellitus and obesity among Tabuk Citizens in Saudi Arabia. The Open Cardiovascular Medicine Journal. 2018; 12:41. Available from: DOI: 10.2174/1874192401812010041 [Accessed: 18th March 2019]. 